Pamiętnik Literacki 2019, 2, s. 171-177

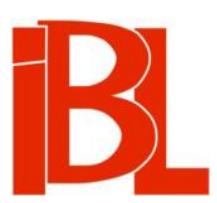

\title{
Julian Gaudenty Kaliszewski w świetle nowych źródel
}

Dorota Samborska-Kukuć 
Pamiętnik Literacki CX, 2019, z. 2, PL ISSN 0031-0514

DOI: $10.18318 /$ pl.2019.2.10

DOROTA SAMBORSKA-KUKUĆ Uniwersytet Łódzki

\section{JULIAN GAUDENTY KALISZEWSKI W ŚWIETLE NOWYCH ŹRÓDEL}

Sam nazywał siebie, znaczaco, Klinem, Wiktor Gomulicki nadał mu w Ciurach sugestywna godność Kleszcza ${ }^{1}$. Ekscentryk, skandalista, weredyk, flaner i dandys, „trochę hipochondryk, trochę schizofrenik"2 - Julian Gaudenty Kaliszewski. Był publicysta, autorem mizantropijnych Pamiętników sceptyka i zaczepnych, w zamierzeniu pamfletowych Moich kochanych rodaków oraz satyrycznych Szkiców, a także najprawdopodobniej Starej i młodej prasy ${ }^{3}$.

mężczyzna średniego wzrostu o długich, swobodnie w tył zarzuconych blond włosach. Czoło jego szeroko rozwinięte podrysowanym jest łukami ciemnych brwi, które jakby na klamerkę zostały spięte dwoma głębokimi zmarszczkami. Badawcze spojrzenie kryło się pod okularami, ale ruchliwe skrzydła jego nosa zdradzały uczucia wewnętrzne, które reszta fizjognomii jakby do maskowania się zmuszała. Usta, z lekka w kątach swoich zaginające się ku dołowi, miały wyraz ironii połączonej z pewnym pobłażaniem ${ }^{4}$.

Zamieszczona w Szkicach autocharakterystyka zbliżającego się do czterdziestki pisarza idealnie współgra $\mathrm{z}$ konterfektem, który przy okazji jego nekrologu wydobyła redakcja „Świata”. Kaliszewski był rówieśnym pozytywistów, ale - poza krótkotrwałą współpracą z „Przeglądem Tygodniowym” ${ }^{6}$ - niewiele go z nimi łączyło. Chciał być literatem, lecz o powieściach miał złe zdanie (na znak dezaprobaty dla tego gatunku podpisywał się niekiedy pseudonimem Nie-Kraszewski), talentu poetyckiego nie posiadał, próbował przekładów z literatury klasycznej, w końcu znalazł dla siebie miejsce jako pamflecista wypowiadający się w krótkich formach paraliterackich: w eseju, szkicu, w osobliwym, odżegnującym się od sentymental-

1 W. Gomulicki, Ciury. T. 3. Warszawa 1907, s. 12-29.

2 D. Świerczyń s ka, Julian Kaliszewski - pisarz zapomniany. „Pamiętnik Literacki” 1986, z. 4, s. 177.

3 Jest to pierwsza polska praca prasoznawcza; wskutek wydania jej pod pseudonimem (Eksdziennikarz) ma ona niepewną atrybucję. Można jednak uznać, że stosując rzetelną i drobiazgową argumentację, D. Świe r czyńska (Walery Przyborowski czy eksdziennikarz? Rozważania o autorstwie „Starej i młodej prasy”. „Pamiętnik Literacki” 1988, z. 3) przekonująco wykazała, że to Kaliszewski, a nie Przyborowski był autorem tej rozprawy.

4 J. G. Kalis zew sk i, Szkice. T. 1. Warszawa 1882, s. 170.

$5 \quad Z$ żałobnej karty. Śp. Julian Kaliszewski (Klin). „Świat” 1909, nr 37, s. 27. Tę samą fotografię zamieścił również J. W. Go mulicki w swoim artykule o Kaliszewskim „Klin”, opublikowanym w „Stolicy” (1960, nr 13, s. 16).

6 Nie ustalono, jakie teksty drukował na łamach „Przeglądu” (a także innych jeszcze czasopism), ponieważ publikował anonimowo. 
ności itinerarium. Specyficzne cechy jego pisarstwa tak punktowała Dobrosława Świerczyńska: „swoboda myśli i sądów, przekora i zadziorność, ostrość sformułowań w stosunku do siebie, do społeczeństwa w ogóle, a do społeczności czytelniczej w szczególności, odwaga w traktowaniu kwestii obyczajowych, krytycyzm wobec osiągnięć i planów warszawskiego pozytywizmu"7.

Kaliszewski był w ostatnim półwieczu kilkakrotnie przez historyków literatury przypominany: najpierw przez Świerczyńską ${ }^{8}$, po dłuższym czasie przez Magdalenę Sadlik i Marię Kobielską, a przed paru laty przez Jana Tomkowskiego i Olgę Szmidt ${ }^{9}$. Renesans ten zawdzięcza literat zapewne swojej naturze trickstera: przekorze, bezkompromisowości poglądów i zuchwalstwu, z jakim je głosił, niewykluczone, że wskutek kompleksu l'esprit de l'escalier, co czyni go interesującym przypadkiem komentatora dookolności. I to zarówno publicznej, manifestującej się w kolektywnych przekonaniach i stereotypach, jak i jednostkowej, cechującej niektóre typy wpływowych ówcześnie jednostek. Ciekawi w pismach Kaliszewskiego nie tylko walor jego dynamicznego, ostrego i cynicznego pióra, nie tylko żelazna konsekwencja, $z$ jaka się wypowiadał, narażając się na ostracyzm towarzyski, ale przede wszystkim nowoczesność, a nawet ponadczasowość spostrzeżeń i diagnoz. Jest to lektura drażniąca fanfaronada, lecz pod powierzchnia błazeństwa - podobnie jak w utworach Witolda Gombrowicza ${ }^{10}$ - czytelnik znajduje poważne, wypływające $z$ wnikliwych obserwacji i głębokich przemyśleń wnioski. Autorzy wymienionych opracowań, poza Świerczyńską, koncentrują się głównie na zagadnieniach satyrycznego pisarstwa Kaliszewskiego, dokonując przeglądu i oceny jego utworów, a uwarunkowania życiowe - co zrozumiałe wobec przyjętej tematyki - przywołują raczej śladowo. (Stosunkowo najwięcej danych biograficznych zawiera artykuł Świerczyńskiej.) Warto zatem poszerzyć je i na podstawie nie eksplorowanej dotąd dokumentacji metrykalnej uzupełnić te cenne poznawczo informacje formujące życiorys i genealogię Kaliszewskiego.

Badaczom nie była dotychczas znana data urodzenia pisarza - ani dzienna, ani

Św i e r c zy ń s k a, Julian Kaliszewski - pisarz zapomniany, s. 178.

8 Dwóm wspomnianym artykułom Świerczyńskiej zawdzięczamy wydobycie Kaliszewskiego z pogłębiającego się zapomnienia, w XX w. bowiem - poza hasłem w Polskim słowniku biograficznym właściwie przed Świerczyńską nie poświęcano uwagi autorowi Pamiętników sceptyka, nie podejmowano żadnych badań nad jego życiem i pisarstwem. Ukazał się wprawdzie szkic J. W. G omulicki e g o o Klinie w tomie Zygzakiem. Szkice - wspomnienia - przekłady (Warszawa 1981), poprzedzony artykułem w „Stolicy”, a zaraz potem, w r. 1983, drobny tekst A. Maria now icza w numerze 15 „Szpilek” (Zapomniany satyryk polski), były to jednak zasłyszane wspomnienia, w których fakty mieszały się $\mathrm{z}$ komerażami.

9 M. Sadlik, „Konfesje samotnych”. W kręgu prozy spowiedniczej 1884-1914. Kraków 2004, s. 31-38. - M. Ko b i els ka, „Złamane pióro eksliterata”? O „Szkicach” Juliana Kaliszewskiego. „Teksty Drugie” 2008, nr 6. - J. To m k o w s ki, Cena niezależności. O eseistyce Juliana Kaliszewskiego. „Studia Medioznawcze” 2013, nr 2. - O. Szmidt, Poszukiwanie przestrzeni krytycznej refleksji. „Pamiętniki sceptyka” Juliana Kaliszewskiego. W zb.: Krótkie rozprawy o modernizmie. Red. B. Obsulewicz, P. Bordzoł. Lublin 2014.

10 Utwory Kaliszewskiego i Gombrowicza (Dzienniki, a przede wszystkim Trans-Atlantyk) mają wiele cech wspólnych w sferze refleksji nad polskimi wadami narodowymi: nieodległe w swej istocie przygany, ta sama czupurność, podobny rodzaj humoru wskazują na szczególną przenikliwość i trafność oglądu skrytą pod maską bufonady. 
nawet roczna. Biobibliografie wskazują tylko domyślnie - na rok 1845 (na jego drugą połowę) lub $1846^{11}$. Powstała też (zapewne wskutek niemożności odnalezienia aktu pod typowanymi latami) wątpliwość dotycząca miejsca jego przyjścia na świat ${ }^{12}$. Problem $z$ odszukaniem daty został spowodowany faktem opóźnionej, bo przesuniętej na r. 1856, ceremonii chrztu, będącej nierzadko oficjalnym zgłoszeniem urodzenia dziecka. Interesujący nas akt znajduje się w warszawskiej parafii pw. Świętego Krzyża; czytamy w nim:

Działo się w Warszawie w Parafii Ś-go Krzyża, dnia ósmego lipca tysiąc osiemset pięćdziesiątego szóstego roku o godzinie piątej po południu.

Stawił się Antoni Kaliszewski, budowniczy Powiatu Warszawskiego, lat pięćdziesiąt mający, w Warszawie pod liczbą dwa tysiące sześćset osiemdziesiąt jeden zamieszkały, w obecności Symeona Pawłowicza, komisarza administracyjnego Cyrkułu pierwszego i jedenastego, i Józefa Bełdowskiego referenta komisji Rządowej Spraw Wewnętrznych i Duchownych, pełnoletnich, w Warszawie zamieszkałych i przedstawił Nam Syna swego, urodzonego tu, w Warszawie, pod liczbą dwa tysiące siedemset sześćdziesiąt sześć litera D, przy ulicy Oboźnej, dnia dwunastego lutego tysiąc osiemset czterdziestego piątego roku o godzinie szóstej wieczór z Jego Małżonki Honoraty Aleksandry z[e] Śliwickich, lat trzydzieści ośm obecnie mającej. Młodzianowi temu na Chrzcie Świętym nadane zostały imiona Gaudenty Julian Antoni Napoleon. Rodzicami Jego chrzestnymi byli Ignacy Mysłakowski z Wiktorią Mysłakowską. Spóźnione spisanie tego aktu Ojciec podał za przyczynę zatrudnienie swoje. Akt ten, przeczytawszy Ojcu i Świadkom, przez Nas i Tychże podpisany został ${ }^{13}$.

Na podstawie tego dokumentu urzędowego można ustalić zatem dzienną datę urodzenia Juliana Kaliszewskiego: 12 II 1845, miejsce: ul. Oboźna 3 (2766d to numer hipoteczny ${ }^{14}$ ), potwierdzić personalia rodziców: Antoni Kaliszewski i Honorata Aleksandra ze Śliwickich, wprowadzić dane osobowe świadków chrztu: małżeństwo Mysłakowskich ${ }^{15}$. Dzięki tym prymarnym informacjom, potraktowanym jako punkt wyjścia, możliwe były dalsze ukierunkowane kwerendy i rozpoznania.

Drugim istotnym dokumentem jest akt małżeństwa rodziców Kaliszewskiego z 1838 roku $^{16}$. Niektóre wynikające $z$ niego informacje były już znane m.in. Świer-

11 Zob. C. Gajkows ka, Kaliszewski Julian Gaudenty. Hasło w: Polski słownik biograficzny. T. 9. Wrocław 1964-1965. - Kaliszewski Julian Gaudenty. Hasło w: Bibliografia literatury polskiej „Nowy Korbut”. T. 14. Warszawa 1973. - Kaliszewski Julian Gaudenty. Hasło w: Zbiór poetów polskich XIX w. Ułożył i oprac. P. Hertz. T. 6. Warszawa 1975. - I. T. [I. Te re s ińs ka], Kaliszewski Julian. Hasło w: Dawni pisarze polscy od początków piśmiennictwa do Młodej Polski. T. 2. Warszawa 2001 , s. 72 .

12 Według nieudokumentowanej sugestii Ter e s iń s ki ej (loc. cit.) pisarz mógł urodzić się w okolicy Iłży.

13 USC Warszawa / parafia Świętego Krzyża, akt urodzenia nr 553 z r. 1856, k. 139. Archiwum Państwowe w Warszawie. Wszystkie przywołane tu akty znajduja się w tym samym zasobie warszawskim, chyba że zaznaczono inaczej. Pisownię i interpunkcję zmodernizowano, pozostawiając jedynie wielkie litery stosowane ze względów grzecznościowych.

14 Identyfikację numerów hipotecznych wraz z odpowiednimi cyrkułami zob. Taryfa domów miasta Warszawy 1873, s. 92, 138.

15 Ignacy Mysłakowski (1795-1856), syn Antoniego i Marianny z Zielińskich, mąż Wiktorii ze Stuartów $1 v$. Kuniowskiej, pochodzący z Mysłakowa pod Sierpcem, był urzędnikiem Heroldii Królestwa Polskiego, wojskowym, uczestnikiem powstania listopadowego - zob. USC Warszawa / parafia św. Jana, akt małżeństwa nr 70 z r. 1842, k. 416; zob. też Rocznik Wojskowy Królestwa Polskiego na rok 1827. Warszawa 1827, s. 43. Kaliszewskich łączyło pokrewieństwo z żoną Mysłakowskiego: była ona stryjenką Kaliszewskiej (siostrą jej ojca).

16 USC Warszawa / parafia Świętego Krzyża, akt małżeństwa nr 189 z r. 1838, k. 652. 
czyńskiej, pozostałe są nowe. Uzupełnione o inne jeszcze metryki i źródła drukowane, wprowadzają szereg kolejnych faktów. Potwierdziła się więc identyfikacja zawodu ojca pisarza, Antoniego, syna Jana i Antoniny z N., urodzonego we wsi Krajewo Białobiel pod Ostrołęką 5 IX 1808, który był architektem. Wiadomo, że po ukończeniu gimnazjum w Łomży i szkoły politechnicznej w Warszawie praktykował w stolicy u cenionych architektów - Aleksandra Groffego i Antoniego Corazziego ${ }^{17}$, przypuszczalnie też współpracował z inżynierem budownictwa Aleksandrem Śliwickim (1786-1839), swoim przyszłym teściem ${ }^{18}$, mieszkającym wówczas w Piotrkowie. W latach 1840-1848 był budowniczym okręgu opatowskiego, do 1879 r. powiatu rawskiego ${ }^{19}$. $\mathrm{Z}$ racji wykonywanego zawodu zapewne rzadko pojawiał się w domu. Na emeryture przeszedł w 1879 r. po śmierci żony. Matka Juliana, Honorata Aleksandra ze Śliwickich, urodzona w styczniu $1816 \mathrm{w}$ Warszawie $^{20}$, była córką wspomnianego tu Aleksandra oraz Marianny Karoliny z Cybulskich (ur. 1787), która zmarła w lipcu 181921, w trzy miesiące po urodzeniu drugiej córki, Katarzyny Klotyldy $^{22}$. W rok później, w lipcu 1820 Śliwicki ożenił się powtórnie ${ }^{23}-$ z Katarzyną Paciorkowską z Błonia (1800-187824). Gdy rodzice Juliana pobierali się, Antoni mieszkał w Warszawie przy ulicy Złotej, a Honorata Śliwicka z macocha w Piotrkowie. O dziadkach Juliana Kaliszewskiego po mieczu nic nie wiadomo - wskutek braku dostępności ksiag ostrołęckich ${ }^{25}$-jedynie to, że w r. 1838 (ślub Kaliszewskich) już nie żyli; także dziadkowie po kądzieli zmarli przed jego urodzeniem.

Honorata i Antoni Kaliszewscy zamieszkali po ślubie przy Nowym Świecie 48. Tam, 4 X 183926, przyszła na świat ich córka, Franciszka Wanda Bogumiła ${ }^{27}$, ale jej urodzenie zgłosił ojciec dopiero po 21 latach, zwłokę tłumacząc... „oczekiwaniem na chrzestnych”28. Kaliszewscy nie zgłaszali również narodzin trójki następnych

Zob. S. Ło za, Architekci i budowniczowie w Polsce. Warszawa 1917, s. 139.

Zob. USC Warszawa / parafia Świętego Krzyża, akt zgonu [Aleksandra Śliwickiego] nr 263 z r. 1839, k. 418.

Zob. J. Gw a rdia k, Architekci i budowniczowie ziemi łomżyńskiej. Słownik biograficzny. Łomża 2003, s. 49.

Zob. USC Warszawa / Cyrkuł II, akt urodzenia nr 191 z r. 1819, k. 49.

Zob. ibidem, akt zgonu nr 301 z r. 1819, k. 76.

Zob. ibidem, akt urodzenia nr 192 z r. 1819, k. 49. Nie odnaleziono aktu zgonu Katarzyny Klotyldy Śliwickiej, ale wiadomo, że w r. 1839 już nie żyła, ponieważ w akcie zgonu Aleksandra Śliwickiego oprócz wdowy wpisana została tylko Honorata Aleksandra - jako jedyna córka. Prawdopodobne, że zmarła w dzieciństwie, w Błoniu, lub we wczesnej młodości - w Piotrkowie.

Zob. USC Błonie, akt małżeństwa nr 14 z r. 1820, k. 77. Archiwum Państwowe w Warszawie, oddział w Grodzisku Mazowieckim. W styczniu 1822 urodził się syn Aleksandra i Katarzyny - Marceli Rudolf (ibidem, akt urodzenia nr 6 z r. 1822, k. 3).

Zob. ibidem, akt zgonu nr 40 z r. 1878, k. 108.

Sprawdzano księgi ostrołęckie $z$ lat 1753-1771 (urodzenia), ale nigdzie nie natrafiono na nazwisko Kaliszewski, być może więc stamtąd pochodziła babka, której nazwiska nie podano ani w akcie małżeństwa, ani w akcie zgonu Antoniego Kaliszewskiego, albo Kaliszewscy przyjechali do Białobieli przed 1808 r. $z$ innej części kraju.

Dotąd podawano rok 1842.

Wszędzie w aktach urzędowych Franciszka Kaliszewska podpisywała się jako Wanda.

USC Warszawa / parafia Świętego Krzyża, akt urodzenia nr 1022 z r. 1860, k. 256. Franciszka Kaliszewska w 1883 r. zostanie żona artysty-muzyka Franciszka Maleszewskiego - zob. USC Warszawa / parafia św. Antoniego, akt małżeństwa nr 118 z r. 1883, k. 189. Przypadki podobnych 
dzieci (znane są tylko metryki ich zgonów): Olimpii, urodzonej przy ulicy Świętokrzyskiej 20 w kwietniu lub maju 1841 i zmarłej w lipcu roku następnego ${ }^{29}$, Napoleona, urodzonego na przełomie lat 1843 i 1844, który zmarł również na Świętokrzyskiej w kwietniu $1844^{30}$, oraz Władysława Tytusa, urodzonego w styczniu 1848 i zmarłego przy ulicy Bednarskiej 5 (nr hipoteczny 2681) w czerwcu $1849^{31}$. Zatem Kaliszewscy, oprócz Juliana Gaudentego, który był ich czwartym z kolei potomkiem, oraz Franciszki Wandy, mieli jeszcze troje dzieci, zmarłych niedługo po urodzeniu.

$Z$ tych rejestrów wynika również, że zanim Kaliszewscy zakupili kamienicę przy ulicy Bednarskiej $5^{32}$, a stało się to już po urodzeniu Juliana, a przed przyjściem na świat Władysława, czyli między r. 1845 a $1849^{33}$, dość często w przeciagu dekady zmieniali adresy (Nowy Świat, Świętokrzyska, Oboźna, Bednarska).

Późniejszy autor Pamiętników sceptyka wychowywał się więc przy Bednarskiej. Ukończył gimnazjum realne mieszczące się przy Krakowskim Przedmieściu ${ }^{34}$ i choć był uzdolniony, podjęte w Szkole Głównej Warszawskiej studia przerwał. Wybrał tryb życia, który odpowiadał jego temperamentowi samotnika i samouka, a który ułatwiała mu zamożność - zagraniczne podróże. Obracał się w kręgach Wiktora Gomulickiego, Juliana Ochorowicza, Władysława Szancera (pseud. Ordon), Felicjana Faleńskiego; jako człowiek dobrze sytuowany wspierał finansowo literatów, których cenił (m.in. Władysława Bełzę, Wacława Grubińskiego). Świerczyńska wnioskuje: „Życie mu się wyraźnie nie układało. W 1879 r. stracił matkę, z która jak się wydaje - nie był związany uczuciowo, w 1885 r. ojca [...]"35. Honorata Aleksandra Kaliszewska zmarła 10/22 VI 1879, mając 63 lata, w Rawie Mazowieckiej ${ }^{36}$, gdzie mieszkała czasowo, gdy Antoni nadzorował tam prace budowlane, i w tym prawdopodobnie mieście została pochowana - brak w codziennej prasie warszawskiej jakiejkolwiek wzmianki o jej zgonie czy o pochówku. Antoni Kaliszewski dożył 77 lat, zmarł w Warszawie 1/13 I $1885 \mathrm{w}$ swoim domu przy Bednarskiej $5^{37}$. Jak zauważa Świerczyńska, pod nekrologiem ogłoszonym w „Kurierze Warszawskim” (1885, nr 14 b, s. 4) widnieją podpisy jedynie córki i zięcia, co wskazywać może nie tylko na brak zainteresowania ze strony syna, ale też na waśnie pomiędzy rodzeństwem $^{38}$. Warto podkreślić, że Kaliszewski nie był świadkiem na ślubie Maleszewskich - fakt znamienny, zważywszy na najbliższe przecież pokrewieństwo.

opóźnień nie były rzadkie (m.in. Maria i Jarosław Konopniccy chrzcili swoje dzieci, gdy te osiagnęły wiek nastoletni lub nawet dorosły), wynikały zazwyczaj z dość swobodnego stosunku do kwestii religijnych i zwiazzanych z nimi ceremonii.

Zob. USC Warszawa / parafia Świętego Krzyża, akt zgonu nr 778 z r. 1842, k. 459.

Zob. ibidem, akt zgonu nr 478 z r. 1844, k. 464.

Zob. ibidem, akt zgonu nr 277 z r. 1849, k. 93.

Ś w i e r c zy ń s k a (Julian Kaliszewski - pisarz zapomniany, s. 174), posiłkując się pismami sądowymi, wspomina o procesach sądowych, jakie prowadziła matka Kaliszewskiego z poprzednimi właścicielami kamienicy, Wessami.

Świerczyńs ka (ibidem) twierdzi, że nastąpiło to w 1848 roku.

Zob. „Rocznik Naukowo-Literacko-Artystyczny” na rok 1905, s. 103.

Ś wi e r c zy ń s k a, Julian Kaliszewski - pisarz zapomniany, s. 177.

Zob. USC Rawa Mazowiecka, akt zgonu nr 151 z r. 1879, k. 106. Archiwum Diecezjalne w Łowiczu.

Zob. USC Warszawa / parafia św. Antoniego, akt zgonu nr 22 z r. 1885, k. 224.

Św i e r c zy ń s ka, Julian Kaliszewski - pisarz zapomniany, s. 177. 
Świerczyńska pisze o niezależności finansowej Kaliszewskiego ${ }^{39}$. Spadek po matce mógłby jednak uzyskać dopiero w r. 1879, po ojcu 6 lat później, a więc musiał posiadać wcześniej inne źródła utrzymania, najpewniej stale sponsorował go ojciec, który dorobił się znacznego majątku na realizacji przedsięwzięć budowlanych; energiczny i rzutki, obracał się w kręgach administracji zaborczej i zbierał zamówienia na przebudowy obiektów nie tylko w Warszawie, ale na terenie całego Królestwa ${ }^{40}$. Znamienne, że Julian nie odziedziczył po ojcu kamienicy przy Bednarskiej $^{41}$, gdzie wcześniej mieszkał „w elegancko umeblowanym mieszkaniu”.

Szczególną rolę odgrywał [...] pierwszy pokój, obwieszony dokoła wizerunkami nagich kobiet, w którym Klin przyjmował gości i w którym mieściły się trzy jego najulubieńsze sprzęty. Po pierwsze wielki gipsowy odlew posagu Wenus Kallipigos; po drugie - głęboki fotel, w którym spędzał po kilkanaście godzin na dobę na medytacjach: w szlafroku, w fezie i w tureckich pantoflach; po trzecie - szafa biblioteczna, wypełniona po brzegi dziełami poetów, filozofów i historyków, i to dziełami w tekstach oryginalnych $[\ldots]^{42}$.

Przypuszczalnie więc otrzymał gotówkę, siostrze - z woli ojca - ustępując nieruchomość. W roku śmierci (a zapewne i przedtem, tj. od śmierci ojca) mieszkał przy ulicy Żurawiej $12^{43}$.

Mimo zamożności i rozmiłowania w kobiecej urodzie Kaliszewski rodziny nie założył. Silniejsze okazało się pragnienie niezależności. Całe życie słabego zdrowia, dotknięty ciężką choroba, zmarł 13/26 VIII 1909 o godzinie drugiej po północy w szpitalu Św. Ducha przy ulicy Elektoralnej ${ }^{44}$. Miał 64 lata. Ciekawe, że w akcie zgonu został wpisany z pominięciem dwu środkowych imion - jako Julian Napoleon, podobnie jak w testamencie ${ }^{45}$. Czy był to przypadek, czy też Kaliszewski celowo posługiwał się szczególnym imieniem, mającym podkreślić jego wybitność? ${ }^{46}$ Anons zawiadamiający o śmierci i pochówku Kaliszewskiego na Powązkach ogłosili siostra i szwagier Maleszewscy ${ }^{47}$, ale, jak donosiła prasa: „Obrzędowi pogrzebowemu w po-

Swiadczą o tym liczne wzmianki w prasie codziennej Warszawy, m.in. w „Kurierze Warszawskim”: 1848, nr 179, s. 874-875 (kamienica w Warszawie przy ulicy Franciszkańskiej, o numerze hipotecznym 1813); 1855, nr 217, s. 1116 (szpital w Grójcu); 1858, nr 316, s. 1662 (kościół i klasztor mariawitek); 1862, nr 81, s. 463 (kościół parafialny w Mszczonowie). Zob. dokumentację O służbie architekta powiatu rawskiego Antoniego Kaliszewskiego (Archiwum Państwowe w Łodzi, sygn. 436) i inne opisy planów architektonicznych sporządzanych przez Kaliszewskiego, m.in. dla podłódzkich Brzezin. Zob. też J. Ka sprzycki, Korzenie miasta. T. 4: Mokotów i Ochota. Warszawa 1996, s. 74 .

41 W roku 1908 mieszkali tam Maleszewscy - zob. Adresy Warszawy rok 1908, s. 560.

42 Gomulicki, Zygzakiem, s. 213.

43 Zob. Adresy Warszawy 1909, s. 131.

44 Zob. USC Warszawa / parafia św. Andrzeja, akt zgonu nr 508 z r. 1909, k. 906. Zgon Kaliszewskiego zgłosili pracownicy szpitala.

45 12-stronicowy testament Kaliszewskiego znajduje się w dokumentacji urzędowej - zob. Kancelaria Generał-Gubernatora Warszawskiego (Seria 3, Wydział 3). Archiwum Główne Akt Dawnych, sygn. 8097.

46 Autokreacja pisarza miała i inne oblicza. W roku 1872 „Dziennik Poznański” (nr 292, s. 3) zamieścił informację: „Julian Kaliszewski, znany autor Szkiców z podróży, który pisywał pod pseudonimem „Klin”, zmarł w tych dniach w Warszawie”. Trudno dociec, czy to rzeczywiście omyłka, czy może, wskazujący na specyficzne poczucie humoru, żart samego Kaliszewskiego.

Nekrolog. „Kurier Warszawski” 1909, nr 237, s. 4. 
rze przedpołudniowej towarzyszył skromny orszak, wieniec był tylko jeden, i to od osoby względnie obcej nieboszczykowi” ${ }^{48}$. Wydaje się więc, że do śmierci pisarza rodzeństwo nie pozostawało w dobrych stosunkach. Maleszewscy jednak, skutecznie podważywszy testament ${ }^{49}$, nie wypełnili woli zmarłego, zapobiegli ukazaniu się jego kontrowersyjnych Pamiętników sceptyka - na których treść składały się karykatury współczesnych Kaliszewskiemu osobistości oraz, zapewne utrzymane w stylu braci Goncourt, realistyczne opisy warszawskich pań lekkich obyczajów ${ }^{50}$ a także opublikowaniu innych dzieł pozostawionych w rękopisach, na których wydanie pisarz przeznaczył określony fundusz pieniężny. Tym sposobem interesująca spuścizna Kaliszewskiego uległa zatraceniu.

Autorów nekrologów Kaliszewskiego łączy przekonanie o niedocenieniu talentu pisarza wskutek braku akceptacji dla jego światopoglądu oraz z powodu negowania sposobu literackiej manifestacji tych przekonań. „Cnotliwa obłuda nie mogła darować śmiałkowi, iż w epoce, gdy wszyscy schlebiali sobie dla udawania siły, ganił wady ogólnonarodowe, wytykał źródła naszej śmiertelnej słabości" - komentowano ${ }^{51}$. Nawet „Rola”, która piórem redaktora naczelnego tak ganiła Moich kochanych rodaków ${ }^{52}$, pisała, że zamilkł: „naraziwszy się różnym klikom i kliczkom”53.

\author{
Abstract \\ DOROTA SAMBORSKA-KUKUĆ University of Łódź \\ ORCID: 0000-0002-1943-6694
}

\title{
JULIAN GAUDENTY KALISZEWSKI IN THE LIGHT OF NEW SOURCES
}

The article is a biographical-genealogical complement to life and activity of Julian Gaudenty Kaliszewski, a Warsaw publicist, author of controversial paraliterary texts, who was active in the years 1868-1888. The regained certificates, especially these of the writer's birth and death, of his parents' wedding and their deaths, of his siblings' deaths, dwelling places, as well as minor corrections of Dobrosława Świerczyńska's key publications allow to complete the blanks in the writer's biography and to introduce a few new conclusions.

Testament śp. Kaliszewskiego (Klina). „Kurier Warszawski” 1909, nr 239, s. 4.

Kwestię tę omawia szczegółowo Świerczyńska (Julian Kaliszewski - pisarz zapomniany, s. 203-205), podkreślając małostkowość Maleszewskiej, wykłócającej się o kilkanaście rubli, „które brat był jej winien z racji jakichś rozliczeń przy podziale majątku w 1883 roku" (ibidem, s. 204).

Zob. Go mulicki, Zygzakiem, s. 211.

Klin (Julian Kaliszewski). Wspomnienie pośmiertne. „Nowa Gazeta” 1909, nr 392, s. 3.

Recenzja Kamienn ego (pseud. J. Jeleń ski e go), zamieszczona w stałej rubryce „Roli” Na posterunku (1887, nr 46, s. 547), była przykładem błyskotliwej zoilowskiej napaści. Pełna szyderstw, w niewielkim stopniu odnosiła się do tekstu Kaliszewskiego, ale raczej do samego autora, który wedle złośliwości Jeleńskiego - miał „zrozumieć ducha czasu” i w „pluciu na rodaków” naśladować "gadzinowe organy berlińskie”. Całość potraktował Jeleński jako „elukubrację” nadająca się „na makulaturę".

Nekrolog. „Rola” 1909, nr 36, s. 559. 